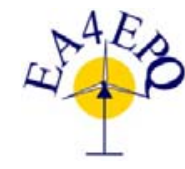

International Conference on Renewable Energies and Power Quality (ICREPQ’17)

Malaga (Spain), $4^{\text {th }}$ to $6^{\text {th }}$ April, 2017

Renewable Energy and Pourer Qualily. Gournal (RE\&PQJ)

ISSN 2172-038 X, No.1 April 2017

\title{
Analysis of yield and power quality of a Micro Photovoltaic generation power plant
}

\section{Gabriela Nunes Lopes ${ }^{1}$, Gabriela Pessoa Campos ${ }^{1}$, Arnulfo Barroso de Vasconcellos ${ }^{1}$, Etiane Oliveira Ponciano de Carvalho', Teresa Irene de Ribeiro de Carvalho Malheiro² e Lutero Paes de Barros ${ }^{3}$.}

\author{
${ }^{1}$ Electrical Engineering Department \\ Malheiro.teresa@gmail.com \\ ${ }^{3}$ Energisa Mato Grosso \\ lutero@terra.com.br
}

Federal University of Mato Grosso - UFMT. Av. Fernando Corrêa da Costa, nº 2367 - Boa Esperança. Cuiabá - MT. ggagabiene@outlook.com, gabriela_pessoacampos@hotmail.com, arnulfo@ufmt.br, etipon@hotmail.com

${ }^{2}$ Federal Institute of Mato Grosso - IFMT. Avenida Sen. FilintoMüller , 953. Cuiabá - MT.

\begin{abstract}
Energy micro and minigeneration in the state of Mato Grosso (MT) - Brazil, in 2015, almost three years after National Electric Energy Agency (ANEEL) regulation by the 482/12 resolution, was made up of only 12 projects. This number jumped to 116 projects in 2016, 74 of which in operation and 42 under implementation, a growth of almost $900 \%$ caused by the incentives that this mode of generation is receiving, especially photovoltaic generation. The state of Mato Grosso, after analysis by the Sector of Mines and Energy Superintendence of Economic Development, was one of the first to exempt this type of generation from goods circulation tax, valid from 01/01/16. Currently, investment return or pay back time is calculated as low as 6 years, encouraging significantly development of the called "green economy" in the state. This article aims to analyze the billing of a consumer unit located in the city of Cuiabá - MT, Brazil, before and after the installation of a micro photovoltaic generation plant with On-Grid system, as well as the efficiency and quality of the electricity generated by it.
\end{abstract}

Key-Words - Micro Generation, Photovoltaic Plant, Power Quality, Power Demand, Energy Consumption.

\section{INTRODUCTION}

A renewable energy source is one whose utilization rate is lower that its rate of renewal. From this concept, with the increasing demand for electricity, as well as the growth of production and population in recent years, these types of renewable energy sources are constant research targets. Based on this, Clean Development Mechanisms (CDM) were developed, and among these, there is the improvement of manufacturing materials with silicon used in converting light energy into electricity. An application of this model is photovoltaic solar energy generation, obtained by the direct conversion of sunlight into electricity.

In 1876 the first photovoltaic apparatus was set up, the result of studies of the structures in the solid state. In its historical context, the physicist Edmond Becquerel in 1939, defines the appearance of a potential difference at the ends of a semiconductor material structure, produced by light absorption. Only in 1956 industrial production began following the development of microelectronics [1]. Brazil, besides having a great potential for solar photovoltaic power generation, has also regions where this technology is the best solution. In isolated communities, solar panels can be used individually, when away from the grid, or in a hybrid form, to save diesel consumption[2]. Aware of these conditions, this work aims to analyze the feasibility of the use of photovoltaic solar energy in a residential system through on-site measurements, demonstrating the relation of the decrease in billed active energy on this Consumer Unit as well as the quality of the electricity generated.

\section{Theoretical foundation}

Figure 01 shows the solar incidence in Brazil in 2016, demonstrating that Mato Grosso state is in one of the areas of greatest solar incidence in Brazil, and this country has a large solar incidence compared with several other countries around the world that have great improvement on photovoltaic generation. 


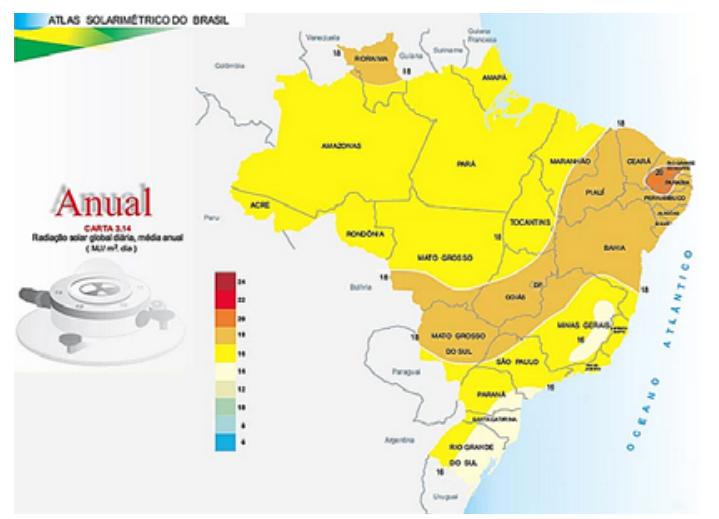

Fig. 01. Representation of sunlight in Brazil released by INPE in 2016.

The expansion of micro and minigeneration projects in Mato Grosso, boosted by tax incentives, has accelerated from the beginning of the year 2016, as illustrated in Figure 2. Photovoltaic plants represent a large portion of this type of generation .

\section{Micro and mini projects of distributed generation in MT}

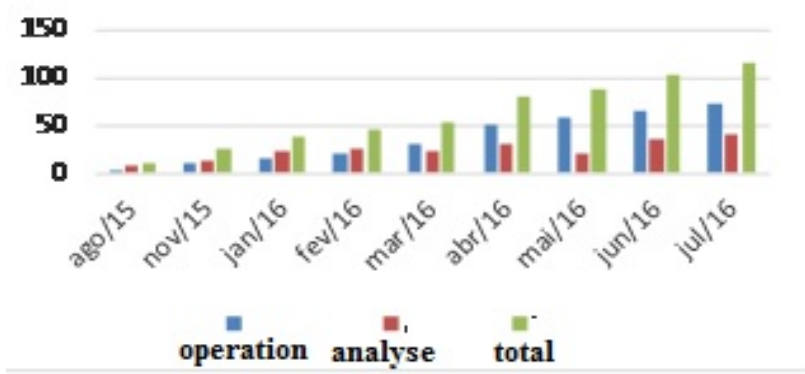

Fig.02. Expansion of distributed generation from the beginning of 2016.

Considering this increase in micro and minigeneration using photovoltaic cells, it becomes important to understand how this type of generation works, and to review existing literature on the types of materials and equipments used in this technology, as well as the models found in the market.

The direct conversion of sunlight into electricity is named photovoltaic effect, and this phenomenon comes from sunlight affecting a cell made of semiconducting materials. You can check the structure of a photovoltaic cell on figure 03.

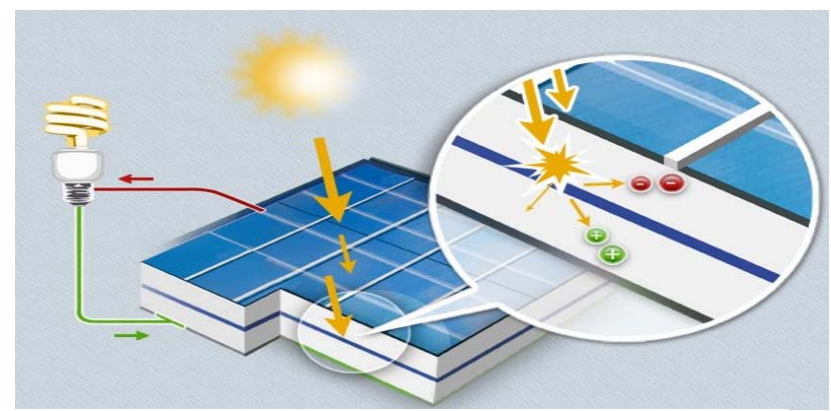

Fig.03. Structure of the solar cell according to Neosolar Energia (2016).

Such photovoltaic cells are fabricated using 95\% silicon and may be built of monocrystalline crystal, polycrystalline or amorphous silicon [1], and Brazil holds $95 \%$ of the world reserves of silicon steel.

The monocrystalline silicon cells have relatively high electrical efficiency, from 12 to $15 \%$, but the techniques used in their production are complex and expensive. A large amount of energy is required in producing them, because of the requirement to use materials in a very pure state and in a perfect crystal structure [5].

Another type of technology used in the production of photovoltaic cells is polycrystalline silicon, which have a lower cost of production because they require less energy in their making, but have a lower electrical efficiency, ranging between $11 \%$ and $14 \%$. This reduction in efficiency is caused by the imperfection of the crystal, due to the manufacturing system [6].

Finally, another technology employed is the use of amorphous silicon cells, which differs from other crystal structures due to its high degree of disorder in the structure of atoms. The use of amorphous silicon for the manufacture of photocells has major advantages, both in electrical properties and in the manufacturing process. Despite having a reduced production cost, because it has a solar radiation absorption in the visible range, the use of amorphous silicon has two disadvantages: the first is a low conversion efficiency compared to mono and polycrystalline silicon cells; second, the cells are affected by a degradation process in the first few months of operation, thus reducing the efficiency over the useful life [1].

Besides all these manufacturing technologies, there are also two ways to develop a photovoltaic power generation system, which are Off-grid and On-grid.

Off-grid systems, as seen in Figure 04, also called selfemployed, are photovoltaic systems that rely solely on solar radiation, making use of a battery bank to make the storage, as well as charge controllers and DC / AC inverters . Off-Grid system have a wide array of uses in regions not serviced by the grid.

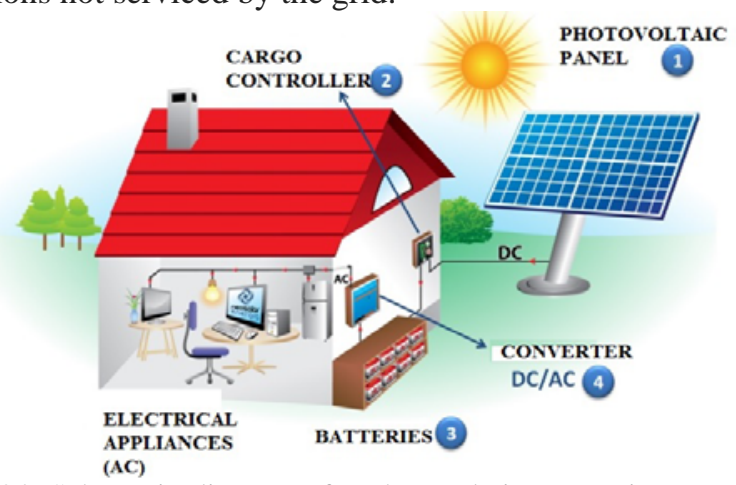

Fig.04. Schematic diagram of a photovoltaic generation system Off-Grid provided by Neosolar Energia in 2016.

On-Grid systems, illustrated in figure 05, also called GridTie, are systems that do not require storage capacity because active surplus energy not consumed is injected in the network. 


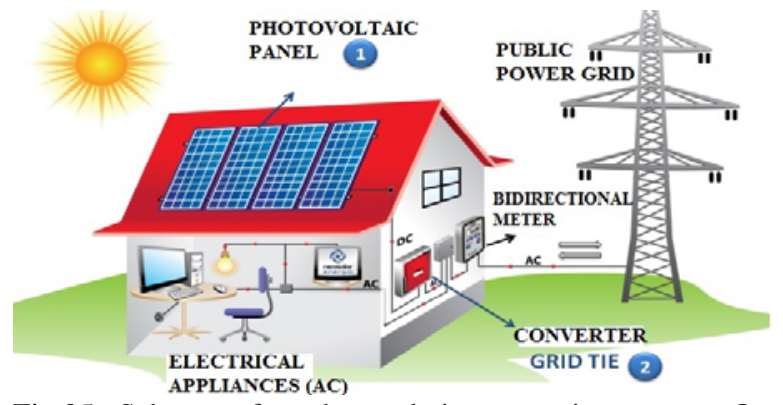

Fig.05. Scheme of a photovoltaic generation system On-grid provided by Neosolar Energia in 2016.

\section{Analysis of the implementation of a photovoltaic plant in a Consumer Unit}

A well dimensioned photovoltaic generation system features low maintenance needs when compared to other power generation systems, such as hydro, besides not having moving parts.

It is emphasized that this form of power generation does not present electromagnetic and audible noise, demonstrating their benefit to residential facilities and telecommunication systems.

It is important to point out that this type of energy production has the characteristic of not releasing harmful gases, especially when compared to other types of power generation, such as thermal generation, in line with classification as a CDM.

In Brazil, the use of photovoltaic systems connected to the network is in early stages of development. However, the prospects for this technology are excellent. Coupled with likely government incentives, as is seen in other countries as well as the current generation of micro credit system, a diffusion of photovoltaic power generation in the brazilian energy matrix is expected. Thus, the correct knowledge of design techniques, and the proper design and installation of photovoltaic systems connected to the network, is extremely important to boost this type of power generation in our country and allow for the economic viability occurred on innovation [3 ].

On the other hand, there are costly characteristics to analyze Photovoltaic Generation Plants, among which the low density of solar energy capture when compared to other forms of power generation systems, and this implies in the need for a lot solar panels if the goal is to capture high potencies.

Another negative feature is that the photovoltaic panel of an autonomous system must be oversized, as it is necessary to take into account climatic changes that may involve the reduction of solar radiation at the site, and it should ensure absortion in these periods.

Based on all the listed parameters, the production of photovoltaic energy is still considered feasible given that it reaches levels around 6\% per month of surplus, when properly dimensioned.

With such insertion in the energy matrix, photovoltaic generation can be considered economical and reliable only if the PV modules operate reliably having a lifetime of 25 - 30 years[8].

Thus, the production of electric energy of a Photovoltaic Generation Micro Power Plant installed in a Consumer Unit located in Cuiabá-MT, Brazil was analyzed. The investment value of implementation of the photovoltaic plant amounted to a total of $\mathrm{R} \$ 88,203.00$, consisting of two kits of 32 panels of $230 \mathrm{~W}$ of the monocrystalline type, and a Grid-Tie Inverter SMA 127 / 220Vac, 60Hz, $7 \mathrm{~kW}$ [4] . It may be seen in Figure 06.

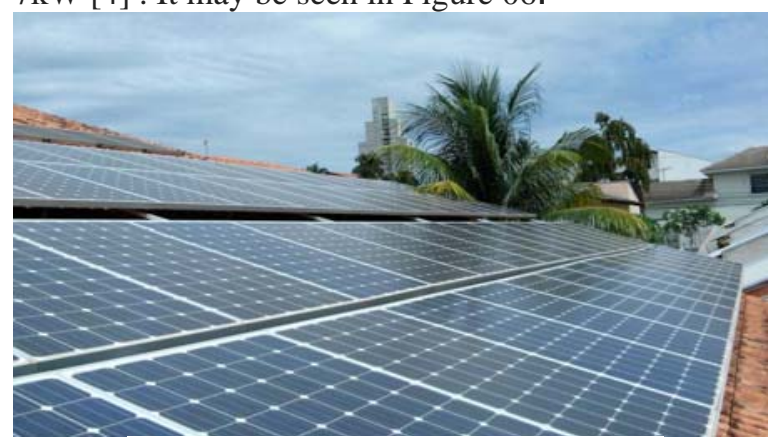

Fig.06. Panels installed in analyzed Consumer Unit.

The system also had converters and switches connected to the home network, besides a disconnect switch for connecting the On-Grid system, as shown in Figure 07.

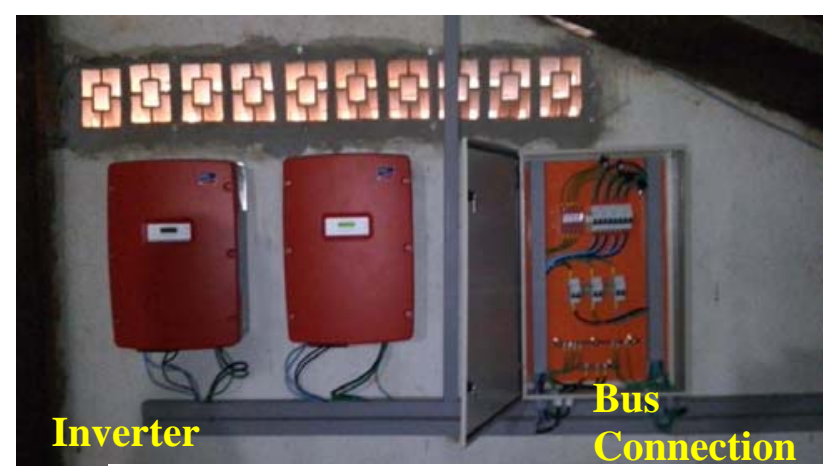

Fig.07. Inverters and circuit breakers of the Consumer Unit with micro generation solar system implanted.

The Consumer Unit where the photovoltaic plant was installed had an average monthly energy consumption of around $1,713 \mathrm{kWh} /$ month, provided by the electric utility company. With the implementation of Photovoltaic Plant, generating on average $774 \mathrm{kWh}$ per month, from March 2015 to March 2016, the energy supplied by the distributor to Consumer Unit (C.U.) was, in average, 717 $\mathrm{kWh} /$ month. Table I shows the monthly consumption of active power supplied by the distributor before the plant facility from August of 2014 to February of 2015.

Table I: Active power consumption of C.U. before the plant installation..

\section{CONSUMER UNIT IN CONVENCIONAL MODE (NO GENERATION)}

\begin{tabular}{|c|c|c|c|}
\hline $\begin{array}{c}\text { Annual } \\
\text { Reference }\end{array}$ & $\begin{array}{c}\text { Energy } \\
\text { consumed by } \\
\text { C.U. }(\mathrm{kWh})\end{array}$ & $\begin{array}{c}\text { Amount } \\
\text { Billed } \\
(\mathrm{kWh})\end{array}$ & $\begin{array}{c}\text { Annual } \\
\text { Savings } \\
\text { (kWh) }\end{array}$ \\
\hline $01 / 08 / 2014$ & 1829,453906 & 1829,45391 & 0 \\
\hline $01 / 09 / 2014$ & 1749,55179 & 1749,55179 & 0 \\
\hline $01 / 10 / 2014$ & 2149,08153 & 2149,08153 & 0 \\
\hline $01 / 11 / 2014$ & 1811,56166 & 1811,56166 & 0 \\
\hline $01 / 12 / 2014$ & 1873,97381 & 1873,97381 & 0 \\
\hline $01 / 01 / 2015$ & 1873,37898 & 1873,37898 & 0 \\
\hline $01 / 02 / 2015$ & 708,234953 & 708,234953 & 0 \\
\hline
\end{tabular}


Table II illustrates the active power consumption values of the Consumer Unit, the generation of active electricity from photovoltaic plant, and the amount saved from March 2015 to March 2016, during which the plant I was already in operation.

Table II: Energy consumed, generated and saved with micro generation in operation.

\section{MICRO GENERATION IN OPERATION}

\begin{tabular}{|r|r|r|r|r|}
\hline $\begin{array}{c}\text { Annual } \\
\text { Reference }\end{array}$ & $\begin{array}{c}\text { Energy } \\
\text { consumed by } \\
\text { C.U. }(\mathrm{kWh})\end{array}$ & $\begin{array}{c}\text { Energy } \\
\text { generated } \\
\text { by PV } \\
\text { (kWh) }\end{array}$ & $\begin{array}{c}\text { Amount } \\
\text { Billed } \\
\text { (kWh) }\end{array}$ & $\begin{array}{c}\text { Annual } \\
\text { savings } \\
\text { (kWh) }\end{array}$ \\
\hline $01 / 03 / 2015$ & 1011,627472 & 1011,62747 & 0 & $\mathbf{1 0 1 1 , 6 2 7}$ \\
\hline $01 / 04 / 2015$ & 1370,852752 & 769,638435 & 601,21432 & $\mathbf{7 6 9 , 6 3 8 4}$ \\
\hline $01 / 05 / 2015$ & 1639,141874 & 913,959372 & 725,1825 & $\mathbf{9 1 3 , 9 5 9 4}$ \\
\hline $01 / 06 / 2015$ & 1676,677558 & 937,309329 & 739,36823 & $\mathbf{9 3 7 , 3 0 9 3}$ \\
\hline $01 / 07 / 2015$ & 1403,225709 & 589,099957 & 814,12575 & $\mathbf{5 8 9} \mathbf{1}$ \\
\hline $01 / 08 / 2015$ & 1225,260748 & 688,384351 & 536,8764 & $\mathbf{6 8 8}, 3844$ \\
\hline $01 / 09 / 2015$ & 1599,534824 & 719,046862 & 880,48796 & $\mathbf{7 1 9 , 0 4 6 9}$ \\
\hline $01 / 10 / 2015$ & 1513,588779 & 601,512468 & 912,07631 & $\mathbf{6 0 1 , 5 1 2 5}$ \\
\hline $01 / 11 / 2015$ & 1605,042777 & 640,931212 & 964,11156 & $\mathbf{6 4 0 , 9 3 1 2}$ \\
\hline $01 / 12 / 2015$ & 1744,608985 & 821,406922 & 923,20206 & $\mathbf{8 2 1 , 4 0 6 9}$ \\
\hline $01 / 01 / 2016$ & 1915,572343 & 713,117896 & 1202,4544 & $\mathbf{7 1 3 , 1 1 7 9}$ \\
\hline $01 / 02 / 2016$ & 1406,319511 & 924,216094 & 482,10342 & $\mathbf{9 2 4 , 2 1 6 1}$ \\
\hline $01 / 03 / 2016$ & 1281,817591 & 735,306215 & 546,51138 & $\mathbf{7 3 5 , 3 0 6 2}$ \\
\hline TOTAL SAVED: & & $\mathbf{1 0 0 6 5 , 6} \mathbf{k W h}$ \\
\hline
\end{tabular}

As can be seen in Table II, in the period of one year, C.U. avoided consuming around $10000 \mathrm{kWh}$ of active power from the distribution system. Based on the data analyzed above, Pay Back of installing this micro photovoltaic generation plant has been calculated to be around 10 years.

\section{Field measurements and analysis of power quality generated by a Photovoltaic Plant}

Initially, active power generated by a module of photovoltaic plant was analyzed for a period of 24 hours, recorded by the inverter, which shows the variation of the active power demand due to the variation of the times of day, as illustrated in Figure 08.

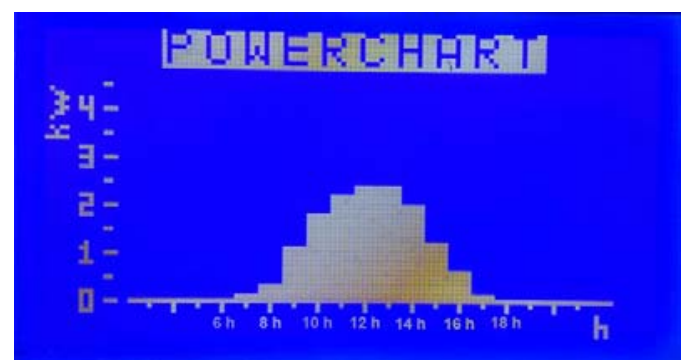

Fig.08. Active power demand of the Photovoltaic Power Plant in 24 hours.

To analyze the quality of energy, the energy analyzer FLUKE 434 was used as shown in Figure 09.

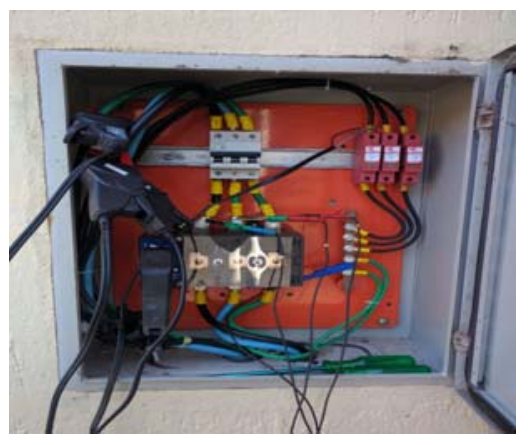

Figure 09: Connection of CTs and voltage tips on the bus of the Photovoltaic Plant.

Initially, generated currents and voltages were registered in each phase in the photovoltaic plant. Figures 10,11 and 12 show the waveforms of the current and generated voltage generated on phases A, B and C, respectively.

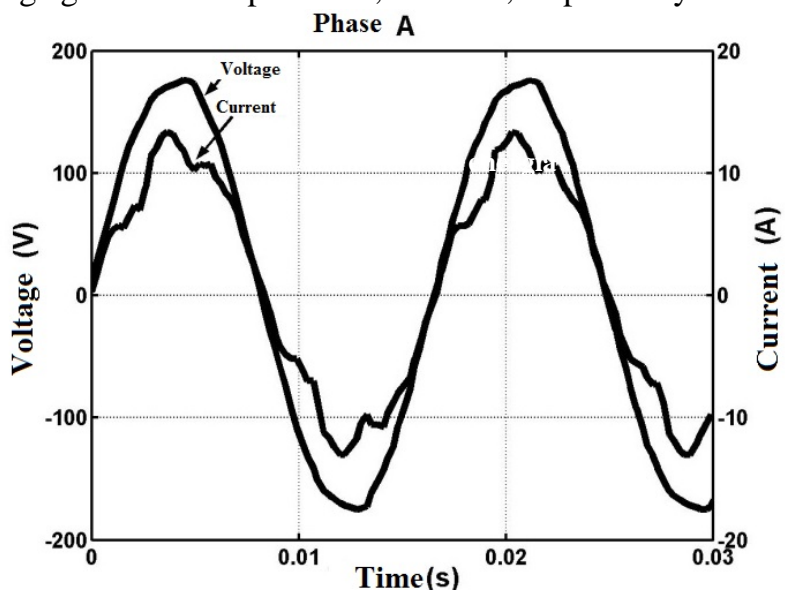

Fig.10. Current and voltage waveform generated in the Phase A.

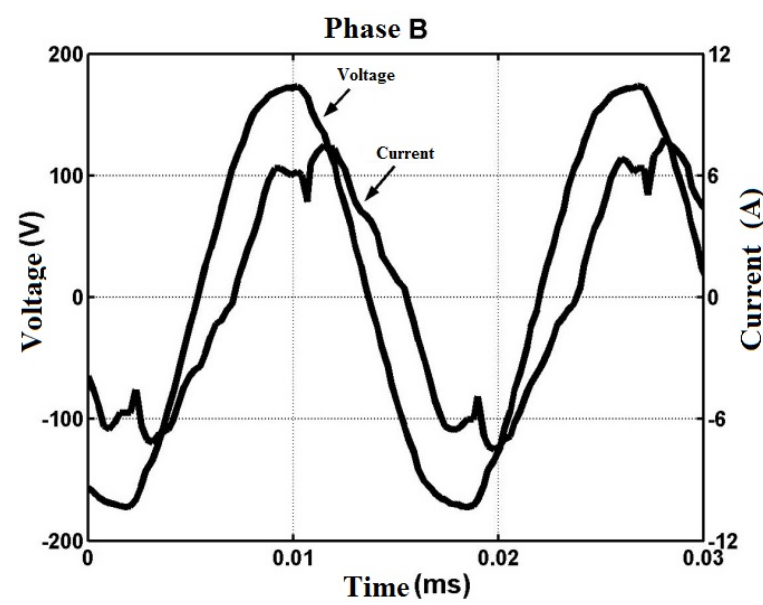

Fig.11. Current and voltage waveform generated in the Phase B. 


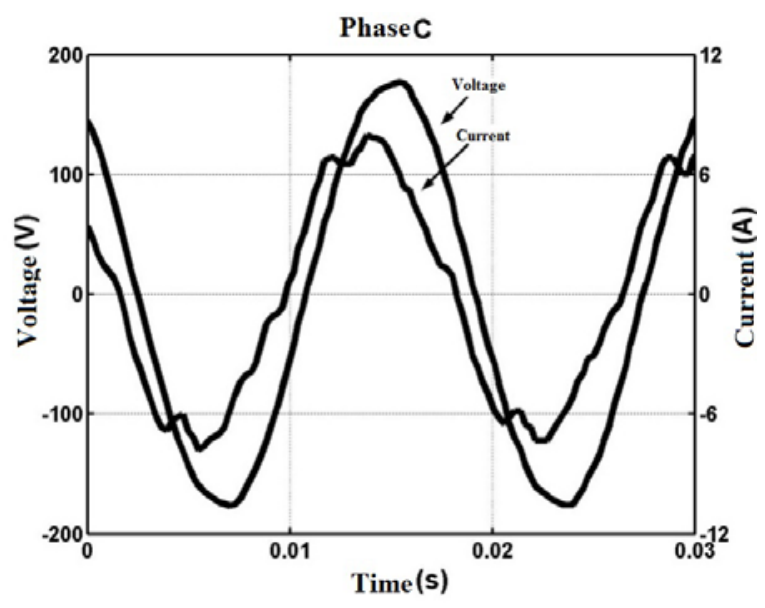

Fig.12. Current and voltage waveform generated in the Phase C.

By inspection of the graphs of figures 10,11 and 12, it is clear that there is a slight harmonic distortion in the waveform of voltages. This can be evidenced in the harmonic spectrum of the phase A voltage that has similar characteristics to the phases $\mathrm{B}$ and $\mathrm{C}$, and the value of total voltage harmonic distortion is within the levels set by the standards of the regulatory bodies, as shown in Figure 13.

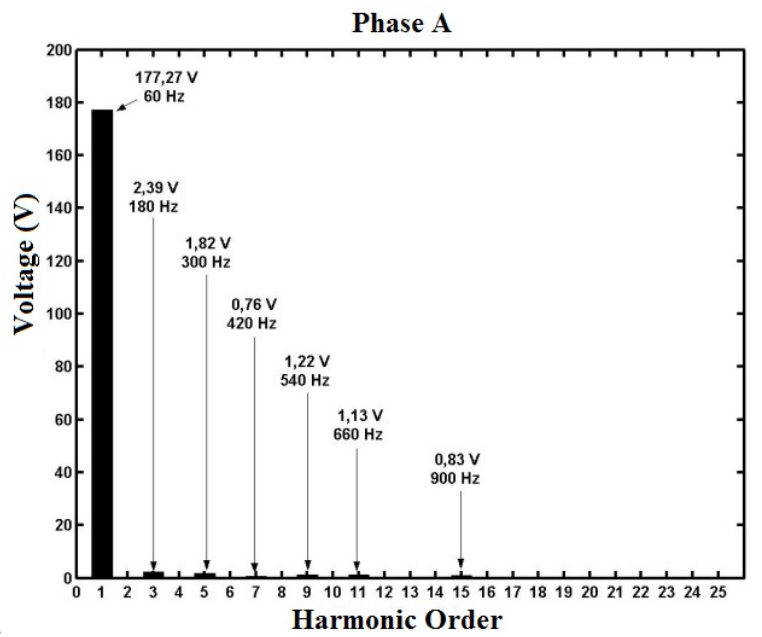

Fig.13. Harmonic spectrum of the voltage waveform on phase A.

Looking again to figures 10,11 and 12 , it is possible to observe, also, that the current waveform on all phases shows a considerable harmonic distortion. The currents harmonic spectrum of phases A, B and C are illustrated in Figures 14, 15 and 16.

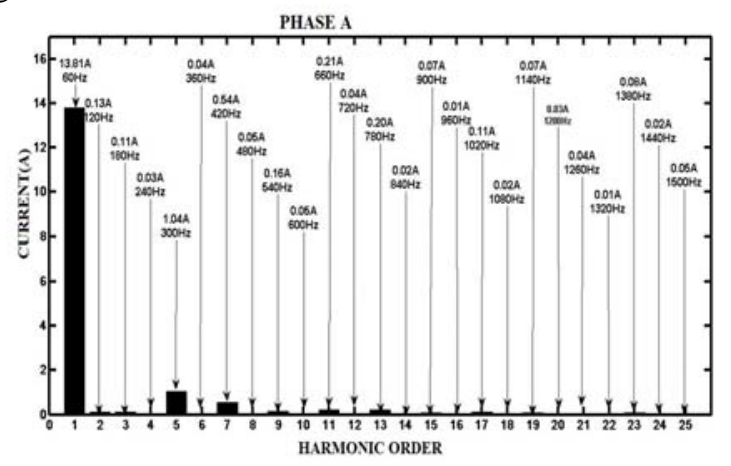

Fig.14. Harmonic spectrum of the current waveform on phase A.

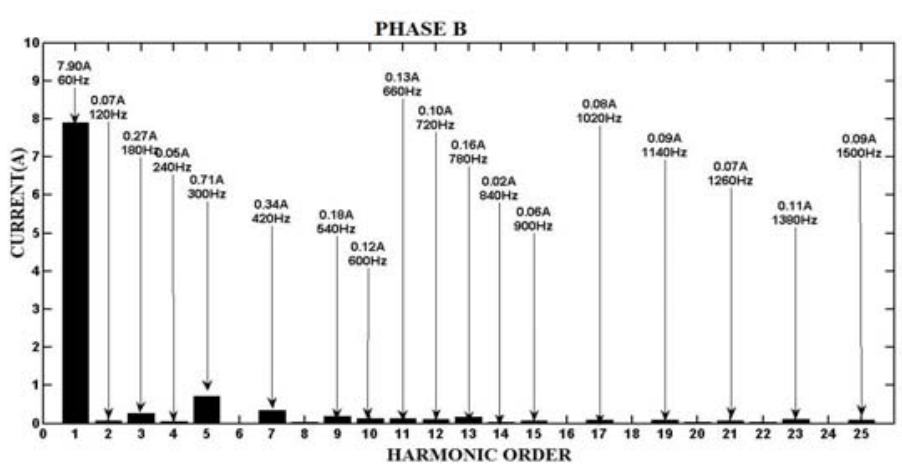

Fig.15. Harmonic spectrum of the current waveform on phase B.

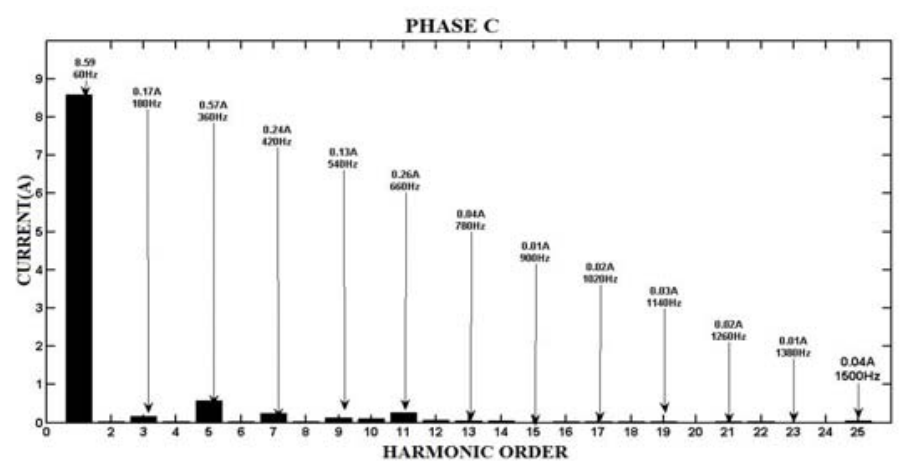

Fig.16. Harmonic spectrum of the current waveform on phase C.

The presence of even harmonics on harmonic spectrum are not characteristic of the electrical system, these may be associated with the lack of symmetry in the operation of converters [7]. The presence of a small portion of the zero sequence harmonics of order 3 and 9 in the form of the current waveform is observed. A greater presence of harmonics of positive and negative sequence order of 5 and 7 has been found, which can interfere with the True RMS currents value in these phases, and these harmonics are characteristic of six-pulse converters used in this project .

The values of apparent, active and reactive power generated by each phase, were also verified, through the energy analyzer Fluke 434 display, as is possible to identify in figure 17.

\begin{tabular}{|c|c|c|c|c|}
\hline & ${ }^{\text {FULL }}$ 月 & $\begin{array}{l}\text { 0:00:06 } \\
B\end{array}$ & 6 & 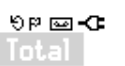 \\
\hline $\begin{array}{l}\text { kJ } \\
\text { kUR } \\
\text { kURR } \\
\text { PF } \\
\text { DPF } \\
\text { Rrms }\end{array}$ & $\begin{array}{l}1.66 \\
1.67 \\
0.18 \\
0.99 \\
1.00 \\
13.6\end{array}$ & $\begin{array}{r}0.80 \\
0.96 \\
0.53 \\
0.84 \\
0.84 \\
7.9\end{array}$ & $\begin{array}{r}0.87 \\
0.98 \\
+0.45 \\
0.89 \\
0.89 \\
7.8\end{array}$ & $\begin{array}{r}3.33 \\
3.60 \\
0.26 \\
0.92 \\
0.93\end{array}$ \\
\hline $\begin{array}{l}\text { Urms } \\
01 / 19 / 16\end{array}$ & $\begin{array}{c}\text { A } \\
122.7 \\
15: 27: 22\end{array}$ & $\begin{array}{c}B \\
122.1 \\
2300.60 \mathrm{~Hz} 3\end{array}$ & $\begin{array}{c}C \\
124.7 \\
3.8 \text { WYE }\end{array}$ & EN50160 \\
\hline PREU & BACK & MEXT & PRINT & \{ks: \\
\hline
\end{tabular}

Fig.17. FLUKE energy analyzer captured the screen, indicating reactive, active and apparent power values on generation at each stage.

Note a capacitive characteristic in phase $\mathrm{C}$, which can be determined by the phasor diagram shown in Figure 18. 


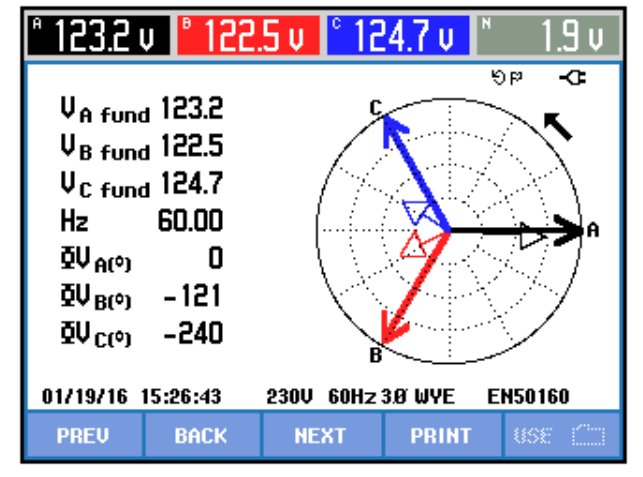

Fig.18. FLUKE energy analyzer captured screen indicating the voltage and current phasor in each phase.

Therefore, the entry of this new type of generation in the electrical system using frequency inverters requires more detailed studies, as energy analyzers are registering capacitive features in these devices depending on the type of switching used.

\section{CONCLUSION}

The Midwest Region of Brazil has one of the largest solar radiation rate in the country, with favorable conditions for the use of photovoltaic generation. Environmental concerns and limited reserves of natural energy resources resulted in increasing use of the renewable energy sources[9]. This explains why photovoltaic type of electricity generation has increased in the State of Mato Grosso, either by tax incentives provided by the Government, either to explore the use of a renewable source, or because it doesn't present the environmental impacts often associated with other conventional forms of energy generation.

Making use of these conditions, this paper presents the performance of the photovoltaic plant of a consumer unit located in Cuiabá city. For performance analysis, data was collected from generation photovoltaic plant and the electricity consumption of the Consumer Unit for a period of 12 months. The plant presented a performance above the estimate contained in your project, generating an expected return of investment between 9 and 10 years.

The currents generated by the photovoltaic plant showed to be non-linear, due to the frequency inverter used in the DC / AC conversion. Its nonlinearity provided current distortion in the presence of harmonic sequences of positive, negative and zero, which may raise the effective value of the current phases of the bus and the neutral conductor through the circulation of zero sequence harmonics.

Therefore, the busbars of the photovoltaic generation of Consumer Units of groups A and B must be constantly monitored to verify the heating conditions of the phase and the neutral conductors due to the presence of currents of multiple frequencies injected.

Through the data recorded in the energy analyzers and meters for billing purposes, in the photovoltaic generation an inductive reactive flow was observed, for phases $\mathrm{A}$ and $\mathrm{B}$ and capacitive for phase $\mathrm{C}$ in the connection bus of consumer unit with generation power plant. The absorption or injection of reactive power inductive or capacitive, respectively, according to the meters, in the bus by photovoltaic generation can contribute to the change of the bus power factor and consequently influence the reactive power surplus calculation both in inductive and capacitive time.

Finally, there is the need for further study on the methods used by the electricity meters in the calculation of the power factor and reactive power, and consequently the impact of absorption or injection of this reactive, observed by these meters in the measurement of photovoltaic plants installed in Consumer Units of groups A and B and their influence on energy charging system. In addition, studies should also include analysis of the interference of the multiple frequencies of the currents injected by photovoltaic generation in Consumer Units, in the buses of the power distribution and in billing meters.

\section{BIBLIOGRAPHIC REFERENCES}

[1] CRESESB. Solar Energy - Principle and Applications. Rio de Janeiro: CRESESB, 2006

[2] Porto, Laura; MINISTRY OF MINES AND ENERGY, "Renewable energy".

[3] MIRANDA, A.B.C.M. Economic feasibility analysis of a photovoltaic system connected to the grid. Graduation Project. Polytechnic School of Rio de Janeiro. Rio de Janeiro. 2014

[4] PEREIRA, Jelsivam da Silva. RESIDENTIAL SYSTEMS FOR THE USE OF SOLAR ENERGY. 2016. 45p. Course Completion Work Electrical Engineering, University of Cuiabá, Cuiabá, 2016.COMETTA, E. Energia solar. São Paulo: Hemus. 1978. ANEEL - NATIONAL ELECTRONIC ENERGY AGENCY,“M\&V Guide - 2.1.”, Brasília - DF: ANEEL, 2014

[5] ALVARENGA, C.A. Solar energy. Lavras: UFLA/FAEPE. 2001.

[6] R. D. Henderson e P. J. Rose, "Harmonics: The Effects on Power Quality and Transformers," IEEE Trans. Industry Applications, vol. 30, 1994, pp. 528-532.

[7] S. M. Filho, "Fundamentals of Electrical Measurements”, $2^{\mathrm{a}}$ ed. Publishing company Guanabara Dois. Rio de Janeiro, 1981.

[8] M. M. D. Afonso ,P. C. M.Carvalho , F. L. M. Antunes , J. J.Hiluy Filho, "Deterioration and performance evaluation of photovoltaic modulesin a semi-arid climate “, Proceedings of the ICREPQ’15. La Coruña (Spain), 25th to 27th March, 2015.

[9] Y. Varetsky, Z. Hanzelka "Modeling Hybrid Renewable Energy System for Micro Grid “, Proceedings of the ICREPQ’15. La Coruña (Spain), 25th to 27th March, 2015. 